DOI: 10.34015/2523-4552.2021.3.05

УдК 343.8

Васюк А. Ю., помічник судді Чернівецького апеляційного суду

\title{
МЕТОДОЛОГІЧНИЙ ІНСТРУМЕНТАРІЙ ДОСЛІДЖЕННЯ ВИКОНАННЯ СУДОВИХ РІШЕНЬ ЩОДО ЗАСУДЖЕНИХ В УКРАЇНІ
}

У статті розкрито методологічний інструментарій дослідження виконання судових рішень щодо засуджених в України. Виокремлено дві його частини. Сформульовано авторське визначення методологічного інструментарію процес наукового пізнання, який відображає спосіб існування, спрямованість розвитку виконання судових рішень щодо засуджених в Україні в абстрактно-теоретичному й емпірично-практичному вимірі.

Ключові слова: методологічний інструментарій, дослідження, виконання, судове рішення, засуджений, персонал.

В статье раскрыт методологический инструментарий исследования выполнения судебных решений по осужденным в Украине. Выделены две его части. Сформулировано авторское определение методологического инструментария процесс научного познания, отражающий способ существования, направленность развития исполнения судебных решений по осужденным в Украине в абстрактно-теоретическом и эмпирически-практическом измерении.

Ключевые слова: методологический инструментарий, исследование, исполнение, судебное решение, осужденный, персонал.

Постановка проблеми. Важливою гарантією i одним із обов'язкових умов будь-якого наукового дослідження вчені в галузі права вважають визначення його методологічного інструментарію. Не порушуючи традицію вітчизняних вчених-теоретиків права, ми в процесі дослідження виконання судових рішень щодо засуджених в Україні застосували власний методологічний інструментарій, а відтак здійснили спробу розкрити авторський підхід та його реалізацію стосовно вирішення проблеми, яка і $\epsilon$ предметом дослідження.
Такий підхід, на нашу думку, має важливе значення, оскільки певною мірою відбиває предмет дослідження через авторське формулювання методологічного інструментарію, починаючи від формулювання відповідних наукових гіпотез 3 проблемних питань дослідження до їхнього доведення або спростування шляхом розкриття кримінальновиконавчих засад виконання судових рішень щодо засуджених в Україні.

Отож, проблема дослідження кримінально-виконавчих засад виконання судового рішення щодо засуджених в Україні грунтується нами 
на проведених раніше дослідженнях у галузі теорії держави і права, кримінального, кримінально-виконавчого та кримінально-процесуального права. Звернення автором саме до таких наукових і прикладних джерел, дозволило встановити відсутність у кримінально-виконавчій науці єдиного підходу щодо методологічного інструментарію саме виконання судового рішення щодо засуджених в Україні.

Аналіз останніх досліджень та публікацій. Важливе значення для порядку і умов відбування засудженим кримінального покарання належить своєчасному виконанню судових рішень, оскільки в них визначається час набрання чинності обвинувального вироку, час прибуття засудженого в установу виконання покарань, час постановки клієнта пробації на облік.

Серед наукових праць у сфері розроблення актуальних проблем кримінально-виконавчих засад виконання судових рішень щодо засуджених в Україні ми виділяємо праці відомих вітчизняних вчених, таких як: А. І. Богатирьов, І. Г. Богатирьов, О. І. Богатирьова, Є. М. Бодюл, О. М. Джужа, О. Г. Колб, А. Л. Колодчина, Н.В.Коломієць, В. Я. Конопельський, I. М. Копотун, В. О. Корчинський, Ю.В.Новосад, О.Г. Михайлик, М. С. Пузирьов, Г. О. Радов, А. Х. Степанюк, В. М. Трубников, С. Я. Фаренюк, В. П. Філонов, О. І. Фролов, С.І.Халимон, О.В.Хорошун, С. В. Царюк, Ю. В. Шинкарьов, О.О.Шкута, О.В.Щербина, I. С. Яковець та ін. Проведений нами детальний аналіз їхніх робіт свідчить, що поза полем зору вчених залишились проблеми виконання судових рішень щодо засуджених в Україні, що і ста- ло визначальним у підготовці цієї статті.

Постановка завдання. Метою цієї статті визначається з'ясуванням можливостей методологічного інструментарію щодо дослідження кримінально-виконавчих засад виконання судових рішень щодо засуджених в Україні.

Виклад основного матеріалу. Оскільки методологічну основу дослідження виконання судового рішення щодо засуджених в Україні становить сукупність загальнонаукових, спеціально-наукових та конкретно-наукових методів ми вирішили довести, що вони використовуються нами під час дослідження не ізольовано, а у поєднанні з іншими методами.

Вищевикладене дозволило нами підтримати наукову думку вітчизняної дослідниці А.Л. Колодчиної, яка вважає, що методологія дослідження має не тільки предметний, а й пізнавальний зміст, оскільки вкрай важливо з'ясувати, якими шляхами, прийомами і методами, у яких логічних формах відбувається перегляд існуючих передумов і підходів до інтерпретації матеріалу, що вивчається [1, с. 318].

У контексті нашого дослідження кримінально-виконавчих засад виконання судових рішень щодо засуджених в Україні ми звернули увагу i на позицію вітчизняного дослідника О. І. Левченко, який вважає, що не можна цілком зрозуміти науку, не склавши уявлення про методологію дослідницького пошуку [2, c. 10].

Дотичним до змісту нашого дослідження є також позиція і вітчизняного вченого О.Г. Колба, який під методологією дослідження розуміє 
своєрідну матрицю чи систему координат, що формує пошук певних прийомів, способів дослідження, необхідних для отримання відповідного результату, який грунтується не лише на обраних методах дослідження певної методичної лінії, а й на визначених статистичних даних з їхніми науковими узагальненнями, певним порядком, планування, а також формується на системному підході до дослідження окремих частин загальної теми, аналізу наукових i нормативно-правових джерел, виведення висновків і розроблення пропозицій стосовно удосконалення виконання і відбування кримінальних покарань та науково обгрунтованих методів, спрямованих на підвищення результату дослідження [3, с. 48-49].

Отож, методологічне обгрунтування дослідження виконання судового рішення щодо засуджених в Україні грунтується нами на необхідності вироблення власного методологічного інструментарії шляхом реалізації загальнонаукових, спеціально-наукових та конкретнонаукових методів. 3 точки зору теорії права, методологічне обгрунтування дослідження виконання судового рішення щодо засуджених в Україні варто розглядати як сучасне наукове вченням про світогляд і систему наукових поглядів, принципів, методів, прийомів і способів пізнання й об'єктивної оцінки діяльності органів пробації і установ виконання покарань щодо досягнення мети виправлення і ресоціалізації засуджених під час виконання судового рішення.

Вітчизняний вчений

О. Г. Михайлик вважає, що саме методологія дослідження - один із важливих інструментаріїв наукового пошуку. Саме методологія має не тільки предметний, а й пізнавальний зміст, тому що вона нероздільно пов'язана 3 переглядом існуючого понятійного апарата, передумов i підходів до інтеграції матеріалу, що вивчається [4, с. 29]. Поділяючи позицію вченого щодо методології ми дійшли висновку, що методологічний інструментарій дослідження має важливе значення.

До речі, на такій позиції щодо методології стоїть і вітчизняна вчена теоретик права О.Ф.Скакун, яка вважає, що важливе значення у проведенні дослідження належить саме методу, під яким дослідниця розглядає систему конкретних способів та принципів досягнення мети дослідження або як систему інструментів дослідження [5, с. 6].

А тому, досліджуючи проблему виконання судового рішення щодо засуджених в Україні, ми поділяємо позицію тих вчених, які методологію, метод і методику співвідносять як філософські категорії загального, спеціального і конкретного. Саме ці категорії і перебувають у діалектичних зв'язках та залежностях.

Отже в нашому дослідженні методологія водночас $\epsilon$ теорією методів пізнання, сукупністю теоретичних принципів, логічних прийомів і способів дослідження явищ. Такий підхід співпадає з позицією вітчизняного вченого В.С. Медведєва, який вважає, що методологія $\epsilon$ системою певних підходів, принципів $\mathrm{i}$ категорій, які опосередковують загальні властивості та зв'язки об'єктивного буття i наукового пізнання [6, с. 78],

A. І. Богатирьов, досліджуючи проблему методології у запобіганні 
професійні деформації у персоналу місць несвободи, прийшов до висновку, що методологію не можна зводити до одного якогось компоненту, зокрема до методу чи вчення про метод, оскільки зміст методології передбачає у собі низку компонентів: світогляд і загальнотеоретичні концепції; загальні філософські закони і категорії; загальні та загальнонаукові методи [7, с. 9].

До речі, слід звернути увагу, що в юридичній літературі методологія розглядається як концептуальна єдність ідей, принципів, методів тощо, які становлять базис (пізнавальний стрижень) певної системи знань. Зокрема, вітчизняний дослідник С. С. Сливка вважає, що «під методологією слід розуміти набуті установки, сформовані погляди, сформований кут зору i взагалі світогляд, який можна реалізувати за допомогою певних методів, підходів і засобів. Самі установки без методів не реалізуються, не є дієвими. Але використання методів потребує певних правил, які загалом іменуються методикою» [8, с. 6].

Отже, одні автори під методологією розуміють сукупність певних теоретичних принципів, логічних прийомів і конкретних способів дослідження предмета науки, інші вказують, що це наука про методи; розуміють їі як систему певних теорій, принципів, законів і категорій, що відображають процес пізнання [9, c. 7].

Вітчизняний вчений Ю. О. Тополь вважає, що методологія юридичної науки - це не тільки весь iї інструментарій у вигляді тих чи інших підходів, способів, методів або принципів, а й теорія про їх використання. Лише у разі такого підходу, на думку автора, методологія юридичної науки здатна виконувати функцію пізнання їі предмета [10, c. 9].

Існують й інші висловлювання 3 цього приводу. Так, зарубіжний $\begin{array}{llll}\text { вчений } & \text { В. С. Швирьов та Б. Г. Юдин }\end{array}$ вважають, що метод наукового дослідження являє собою шлях і спосіб вирішення наукового завдання [11, с. 13-14], а вітчизняні дослідники О.Г. Данильян, В. М. Тараненко зазначають, що методика визначається як сукупність, послідовність, порядок використання конкретно наукових (прикладних) методів дослідження [12, с. 138],

Цікавою з позиції нашого дослідження $є$ думки вітчизняних вчених теоретиків С. Д. Гусарева та О. Д. Тихомирова, які під методологію юридичної науки розуміють систему принципів і способів організації, побудови та здійснення теоретико-пізнавальної юридичної діяльності в галузі дослідження державно-правової дійсності, а також вчення про цю систему [13, с. 34]. Інший вітчизняний вчений теоретик П. М. Рабінович вважає, що методологія це система підходів, способів наукового дослідження і теоретичні засади їх використання при вивченні правових явищ [14, с. 619]. Щодо інших вчених то кожен з них розуміє методологію власного дослідження за власним вибором. I цьому $\epsilon$ певне обгрунтування.

По-перше, предмет дослідження не може характеризуватися тільки загальною методологією, але їі враховувати обов'язково потрібно, оскільки це дозволяє вибрати ті методи, які розкривають зміст предмету наукового пошуку. По-друге, у змісті кожної науки присутні певні 
особливості предмету дослідження, тому методи наукового пізнання можуть мати місце тоді, коли дослідник враховує їх не тільки для грунтовного забезпечення проведення власного дослідження, а і вироблення саме авторського методологічного інструментарію.

До речі, вітчизняні науковці $\begin{array}{ll}\text { A. I. Грабченко, } & \text { В. О. Федорович, }\end{array}$ Я. М. Гаращенко методи дослідження класифікують за різними ознаками: за рівнем пізнання - емпіричні й теоретичні; за точністю припущень детерміністичні й схоластичні, або ймовірно-статистичні; за функціями, які вони здійснюють у пізнанні методи систематизації, пояснення й прогнозування; від конкретної галузі дослідження - фізичні, біологічні, соціальні, технічні тощо. 3 широкого погляду, методи дослідження поділяються на загальнонаукові (тобто вони можуть бути методами й емпіричного, i теоретичного дослідження) і спеціальні, що застосовуються в конкретній галузі науки $[15$, c. 15$]$.

Однак більшість вчених і ми $є$ їхніми прихильниками, крім загальнонаукових, виокремлюють конкретно-наукові методи, які застосовуються в окремих науках або в кількох близьких між собою наукових дисциплінах. Вони поділяються на дві групи: міждисциплінарні та спеціальні [16, с. 93].

Інші визначають такі рівні методології: філософський (фундаментальний), загальнонауковий (емпіричний, теоретичний та змішаний методи) та конкретно-науковий (догматичний метод) [17, с. 47]. Наприклад вітчизняний вчений В. П. Кохановський поділяє всі методи на п'ять основних груп: філосо $ф-$ ські, загальнонаукові, окремі методи (сукупність способів, принципів пізнання, дослідних прийомів і процедур, що використовуються в науці: методи механіки, фізики, біології і соціально-гуманітарних наук), дисциплінарні методи (система прийомів, що застосовуються в тій або іншій науковій дисципліні, які входять в яку-небудь галузь науки або виникли на стиках наук), методи міждисциплінарного дослідження (сукупність низки синтетичних, інтегральних способів (що з'являються внаслідок поєднання елементів різних рівнів методології) [18, с. 185].

Загальнонаукові методи використовуються в переважній більшості наук, наукових дисциплін i напрямів. Ці методи поділяються на дві великі групи: традиційні і сучасні (модерні), і $є$ дещо умовними. Традиційно загальнонауковими методами є: спостереження, аналіз і синтез, індукція і дедукція, порівняння й аналогії, узагальнення й абстрагування, метод експерименту. До сучасних (модерних) загальнонаукових методів належать: метод моделювання, системний, формалізації, ідеалізації, аксіоматико-дедуктивний $[16$, c. 87$]$

Отож, обрання методологічного інструментарію дослідження кримінально-виконавчих засад виконання судових рішень щодо засуджених в Україні залежить від багатьох факторів, але в його основі мають перебувати обов'язкові методи: діалектичний; порівняльно-правовий, історичний; історико-правовий, соціологічний та догматичний. Меншою мірою вченими застосовуються такі методи, як: метод структурносистемного аналізу; формально-юридичний; статистичний; формально- 
логічний; системно-структурний; та систематичний метод.

Ми в процесі визначення методологічного інструментарію дослідження кримінально-виконавчих засад виконання судових рішень щодо засуджених в Україні звернули увагу на позицію вітчизняного вченого О. О. Дударова, який у власному дослідженні «Проблеми кримінально-правової охорони системи оподаткування України» використав такі методи дослідження як: синергетичний, логіко-догматичний, герменевтичний, історико-порівняльний, історико-лінгвістичний, метод лінгвістичної інтуїції, системний, це дозволило йому запропонувати науковій спільноті власний методологічний інструментарій $[19$, с. 5].

Важливого значення методологічний інструментарій дослідження кримінально-виконавчих засад виконання судових рішень щодо засуджених в Україні набуває під час вивчення емпіричної бази дослідження з урахуванням іï специфіки вияву. Саме емпірична база дослідження дозволила узагальнити їх у такі групи:

1) соціологічні прийоми і засоби (спостереження, анонімні опитування засуджених, експертні оцінки вчених у галузі кримінальновиконавчого права, анкетування персоналу установ виконання покарань та уповноважених органів пробації);

2) засоби, які застосовуються в оперативно-розшуковій діяльності оперуповноважених установ виконання покарань;

3) порівняльний аналіз практики виконання судових рішень щодо засуджених в Україні та у зарубіжних країнах;
4) аналіз рішення Європейського суду з прав людини щодо порушень виконання судових рішень щодо засуджених в Україні.

Отож, узагальнюючи вищевикладене робимо висновок, що звернення нами до методологічного інструментарію дослідження виконання судових рішень щодо засуджених в Україні через призму кримінально-виконавчих засад дозволило обрати та обгрунтувати найбільш ефективні методи наукового пізнання (зокрема: діалектичний; історикоправовий; логіко-граматичний; системно-структурний; соціологічний; статистичний; моделювання).

При цьому доведено, що, незважаючи на існування різних методик щодо дослідження кримінальновиконавчих засад, ми вважаємо, що саме через призму вивчення виконання судових рішень щодо засуджених в Україні можна об'єктивно оцінити стан вітчизняного кримінально-виконавчого законодавства в даній сфері і запропонувати шляхи удосконалення. Отже, наведений вище методологічний інструментарій кримінально-виконавчих засад виконання судових рішень щодо засуджених в Україні визначили засадничі (базові) положення нашої дисертації. Більше того, їх осмислення сприятиме вибудовуванню логічно узгодженої системи знань виконання судових рішень щодо засуджених в Україні.

Висновки. Вищевикладене дозволяє на надати наступне визначення методологічного інструментарію виконання судових рішень щодо засуджених в Україні через призму кримінально-виконавчих засад - це процес наукового пізнання, який відображає спосіб існуван- 
ня, спрямованість розвитку виконання судових рішень щодо засуджених в Україні в абстрактно-

\section{теоретичному й}

практичному вимірі. емпірично-

\section{Список використаних джерел}

1. Колодчина А. Л. Методологія дослідження реалізації Україною міжнародних стандартів у сфері захисту прав засуджених в місцях несвободи. Прикарпатський юридичний вісник. 2018. № 2 (23) С. 318-322.

2. Левченко O.I. Проблеми правового регулювання суспільних відносин: загальнотеоретичні аспекти. Вісник Луган. Держ. ун-т внутр.справ ім. Е. О. Дідоренка. 2012. 528 c.

3. Кримінально-виконача система діяльності прокуратури у сфері виконання покарань: навч. посіб. / А. В. Боровик, Ю. В. Новосад, О. Г. Колб, та ін.; за заг. ред. д-ра юрид. наук, проф. О.Г. Колба. Луцьк: СПД Гадяк Ж. В. друкарня «Волиньполіграф», 2020. $640 \mathrm{c}$.

4. Михайлик О. Г. Насильство в установах виконання покарань України: теорія і практика : монографія. Київ : ВД «Дакор» , 2019. 434с.

5. Скакун О. Ф. Теорія права і держави: підручник. 4-те вид. допов. і переробл. Київ: Алерта, 2014. 320 с.

6. Медведєв В. С. Психологія злочинної діяльності : навч. посіб. Київ. 2012. 204 с.

7. Богатирьов А. І. Запобігання професійні деформації у персоналу місць несвободи / за заг. ред..проф. В. С. Медведєва. Київ : ВД «Дакор» 2016. 198 с.

8. Сливка С. С. Вступ до методології філософії права: методологічні вказівки для самостійної роботи (для студентів магістратури). Львів : ЛДУВС. 2008. 24 с.

9. Загальна теорія держави і права : навч. посіб. / за ред. В. В. Копєйчикова. Київ : Юрінком Інтер. 2001. 320 с.

10. Тополь Ю. О. Деякі проблеми методології сучасної юридичної науки. Вісник Хмельницького інституту регіонального управління та права. 2002. № 1. С. 8-11.

11. Швырев В. С., Юдин Б. Г. Методологический анализ науки: его сущность, основные типы и формы. Москва : Знание. 198064 с.

12. Данильян О. Г., Тараненко В. М. Основи філософії. Харків : Право. 2003. 352 с.

13. Гусарев С. Д., Тихомиров О.Д. Юридична деонтологія (Основи юридичної діяльності) : навч. посіб. Київ: Знання, 2005. 655 с.

14. Рабинович П. М. Методологія юридичної науки. Юридична енциклопедія : в 6 т. Т. 3. Київ, 2001. С. 618-619.

15. Грабченко А. І., Федорович В. О., Гаращенко Я. М. Методи наукових досліджень : навч. посібник; Нац. техн. ун-т «Харків. політехн. ін-т». Харків : НТУ «ХПІ», 2009. 142 c.

16. Крушельницька О.В. Методологія та організація наукових досліджень: навч. посіб. Київ, 2009. 192 с.

17. Хилюк С. В. Методологія дисертаційних досліджень з питань Особливої частини кримінального права України. Кримінальне право України. 2006. № 5. С. $43-53$.

18. Кохановский В. П. Философия и методология науки. Ростов на Дону, 1999. С. $182-186$.

19. Дудоров О.О. Проблеми кримінально-правової охорони системи оподаткування України : автореф. дис. ... д-ра юрид. наук : 12.00.08. Київ, 2007. 37 с. 


\section{References}

Kolodchina, A. L. (20188). Metodologiya doslidzhennya realizaciyi Ukrayinoyu mizhnarodnih standartiv $\mathrm{u}$ sferi zahistu prav zasudzhenih $\mathrm{v}$ miscyah nesvobodi. Prikarpatskij yuridichnij visnik, 2 (23), 318-322.

Levchenko, O.I. (2012). Problemi pravovogo regulyuvannya suspilnih vidnosin: zagalnoteoretichni aspekti. Visnik Lugan. Derzh. un-t vnutr.sprav im. E. O. Didorenka.

Kriminalno-vikonacha sistema diyalnosti prokuraturi u sferi vikonannya pokaran: navch. posib. / A. V. Borovik, Yu. V. Novosad, O. G. Kolb, ta in.; za zag. red. d-ra yurid. nauk, prof. O. G. Kolba. Luck: SPD Gadyak Zh. V. drukarnya »Volinpoligraf», 2020. 640 s.

Mihajlik O. G. Nasilstvo $v$ ustanovah vikonannya pokaran Ukrayini: teoriya i praktika : monografiya. Kiyiv : VD «Dakor», 2019.434s.

Skakun O. F. Teoriya prava i derzhavi: pidruchnik. 4-te vid. dopov. i pererobl. Kiyiv: Alerta, 2014. $320 \mathrm{~s}$.

Medvedyev V. S. Psihologiya zlochinnoyi diyalnosti : navch. posib. Kiyiv. 2012. 204 s.

Bogatirov, A. I. (2016). Zapobigannya profesijni deformaciyi u personalu misc nesvobodi / za zag. red..prof. V. S. Medvedyeva. Kiyiv : VD «Dakor».

Slivka, S. S. (2008). Vstup do metodologiyi filosofiyi prava: metodologichni vkazivki dlya samostijnoyi roboti (dlya studentiv magistraturi). Lviv : LDUVS.

Zagalna teoriya derzhavi i prava : navch. posib. / za red. V. V. Kopyejchikova. Kiyiv : Yurinkom Inter. 2001. $320 \mathrm{~s}$.

Topol, Yu. O. (2002). Deyaki problemi metodologiyi suchasnoyi yuridichnoyi nauki. Visnik Hmelnickogo institutu regionalnogo upravlinnya ta prava, 1, 8-11.

Shvyrev V. S., Yudin B. G. Metodologicheskij analiz nauki: ego sushnost, osnovnye tipy i formy. Moskva : Znanie. $198064 \mathrm{~s}$.

Danilyan O. G., Taranenko V. M. Osnovi filosofiyi. Harkiv : Pravo. 2003. 352 s.

Gusarev S. D., Tihomirov O. D. Yuridichna deontologiya (Osnovi yuridichnoyi diyalnosti) : navch. posib. Kiyiv: Znannya, 2005. 655 s.

Rabinovich P. M. Metodologiya yuridichnoyi nauki. Yuridichna enciklopediya : v 6 t. T. 3. Kiyiv, 2001.

Grabchenko, A. I., Fedorovich V. O., Garashenko Ya. M. (2009) Metodi naukovih doslidzhen : navch. posibnik; Nac. tehn. un-t «Harkiv. politehn. in-t». Harkiv : NTU «HPI».

Krushelnicka O. V. Metodologiya ta organizaciya naukovih doslidzhen: navch. posib. Kiyiv, 2009.

Hilyuk, S. V. (2006). Metodologiya disertacijnih doslidzhen z pitan Osoblivoyi chastini kriminalnogo prava Ukrayini. Kriminalne pravo Ukrayini, 5, 43-53.

Kohanovskij V. P. Filosofiya i metodologiya nauki. Rostov na Donu, 1999.

Dudorov, 0. 0. (2007). Problemi kriminalno-pravovoyi ohoroni sistemi opodatkuvannya Ukrayini : avtoref. dis. ... d-ra yurid. nauk. Kiyiv, 2007. 37 s.

\section{A. Vasyuk, Assistant Judge of the Chernivtsi Court of Appeal}

\section{Methodological toolkit for the study of the execution of court decisions on convicts in Ukraine}

The article discloses methodological tools for studying the implementation of court decisions on convicts in Ukraine. Two parts of it are highlighted. An important guarantee and one of the prerequisites of any scientific research, scientists in the field of law consider the definition of methodological tools. Without violating the 
tradition of domestic law theorists, in the process of studying the implementation of court decisions on convicts in Ukraine, we used our own methodological tools, and then made an attempt to reveal the author's approach and its implementation regarding the solution of the problem, which is the subject of the study.

In our opinion, this approach is important, since it reflects to some extent the subject of the study through the author's wording of methodological tools, from the formulation of relevant scientific hypotheses on problematic research issues to their proof or refutation, by revealing from the penal framework the execution of court decisions on convicts in Ukraine.

Thus, the problem of the study of the penal framework for the implementation of the judicial decision concerning convicts in Ukraine is based on previous studies in the field of State theory and law, criminal, penal enforcement and criminal procedure law.

The author's appeal to such scientific and applied sources made it possible to establish the lack of a unified approach to methodological tools in penal science precisely the execution of the court decision on convicts in Ukraine.

Since the methodological basis of the study of the execution of the court decision on convicts in Ukraine is a set of nationwide scientific, specially scientific and specifically scientific methods, we decided to prove that they are used by us during the study not in isolation, but in combination with other methods.

The author's definition of the methodological toolkit is the process of scientific knowledge, reflecting the mode of existence, the direction of development of the execution of court decisions on convicts in Ukraine in the abstract, theoretical and empirical-practical dimension.

Thus, the methodological justification for the study of the implementation of the court decision concerning convicts in Ukraine is based on the need to develop its own methodological tools through the implementation of nationwide scientific, special scientific and specifically scientific methods.

Keywords: methodological tools, research, execution, court decision, convict, staff. 